\title{
Research on Developing Vocational College Students' Creativity Based on Task-based Teaching Method
}

\author{
Xiaoyan Liu \\ Heilongjiang Tourism College, Harbin 150086, China \\ E-mail: xiaoyanliu68@yahoo.com
}

Ya Liu

The First Affiliated Hospital of Heilongjiang University of Chinese Medicine

Harbin 150040, China

\begin{abstract}
This paper is intended to explore the influence of the task-based teaching method on vocational college students in the course of Auto Electronic Control Technology. In order to achieve this goal, this research, based on the principles of universality and exploitability of creativity, takes teaching experiments. Two tools are employed in this research: one is Williams' Creativity Scale, which is used to measure the examinee's creative personality; the other is an investigation on students' attitudes towards the task-based teaching method. As is shown in our research, this method is quite popular with a majority of students, which improves students' imagination, adventure, challenge and creativity, hence an effective way to improve students' creativity.
\end{abstract}

Keywords: Task-based teaching method, Creativity, Adventure, Curiosity

\section{Introduction}

Innovation provides inexhaustible motivation for a nation's prosperity as well as the soul for a nation's advance (Jiang, 1995). In current knowledge economy, a nation's competitiveness mainly depends on its innovative ability. In current Chinese educational environment, it is one important project related to vocational education how to cultivate students' innovative ability and to enable China to edge into the rank of innovative countries. Accordingly, in recent years, the Ministry of Education is actively promoting curriculum development as well as curriculum reform led by projects and driven by tasks in vocational colleges in order to improve students' ability in solving problems. It has been a vital issue how to cultivate students' ability of putting what they have learnt into practice and independent innovation and to make them modern technicians with innovative ability and independent thinking during the process of curriculum reform. This paper is intended to explore the influence of the task-based teaching method on vocational college students in the course of Auto Electronic Control Technology. The following goals are to be achieved:

(1) Exploring the influence of different teaching methods (the task-based teaching method and the traditional teaching method) on the development of students' innovative ability in the course of Auto Electronic Control Technology.

(2) Learning about students' attitudes towards the function of the task-based teaching method employed in Auto Electronic Control Technology in enhancing creativity.

(3) Putting forward assumptions on further research.

\section{Theoretical Basis for the Cultivation of Students' Creativity}

\subsection{Universality of Creativity}

Despite his intelligence, personality, education or knowledge accumulation, anyone is able to produce new ideas, behaviors or have new acquisition, which reflects the universality of creativity. As for college students, creativity is particularly special. So it is critical to find out how to improve students' creativity during the teaching process.

\subsection{Exploitability of Creativity}

There is a great disparity in individual creativity, but actually every person can have his creativity improved through education and training, which is what we call "exploitability of creativity". In theory, it is shown in brain sciences originating in 1990s that human brain has limitless potentials. According to existing material, a person can only use less than $10 \%$ of his brain power in his whole life. 


\section{Subject and Conditions}

\subsection{Subject}

Two classes in Grade 2007 of Auto Electronic Technology in Tourism College of Heilongiiang are chosen as the subject of this research, Class One as the experiment class and Class Two as the control class. Still based on the two classes' organization and scale, we chose 61 samples, in which 60 ones were valid since one student offered incomplete material.

\section{Insert Table 1 Here}

Lavin (1988) points out that no experiment on cooperative learning structure can be established if it lasts less than two weeks or ten hours. Therefore, this research lasted from September 2008 to January 2009, covering the stages of preparation, experiment and post-experiment test and so on.

\subsection{Teachers}

Runco (1990) emphasizes the importance of innovative teachers in cultivating innovative students. With their divergent thinking, innovative teachers are able to dig out students' deep-buried curiosity and creativity and develop students' ability to turn recessive abilities into visible ones. Therefore, we invited excellent teachers with profound science quality, rich teaching experience and creativity. In addition, in order to guarantee the conduction of experiment, we also have some discussions with these teachers on the significance of this task-based teaching method, instruction and experiment of cooperative skills.

\subsection{Teaching Material}

Auto Electronic Control Technology and Instructions on Auto Electronic Control Technology Tasks written by Liu Xiaoyan for vocational college and published by Chemical Industry Press were major textbooks for the experiment class, which are produced with the joint efforts of the experiment team, some other colleges as well as three enterprises during the operation process with the guidance of projects and driven by practical tasks occurring in enterprises. In the control class, Auto Electronic Control Technology written by Yuan Feng and published by China Machine Press in 2004 was used.

\subsection{Teaching Methods}

The task-based teaching method was employed in the experiment class in which specific tasks were based on to arrange theoretical learning and practical instruction while the traditional method was employed in the control class in which teachers began the class with theoretical teaching and then moved on to experiments or practice.

\subsection{Restrictions}

Restricted by the former class structure, the number of students and so on, we cannot have random true experiments but quasi-experiments.

(1) Due to the limitations in manpower, capital and time, we cannot have research and comparison on the students in other vocational colleges.

(2) Due to limited time, only a one-term experiment can be conducted to study the influence of the task-based teaching method on students' creativity.

(3) Neither the experiment group nor the control group can be randomly adjusted due to the formerly established pattern of groups.

\section{Measurement Tools}

Two tools are employed in this research: one is questionnaire investigation on students' attitudes toward the task-based teaching method to learn about students' attitudes; the other is William's Creativity Scale to measure the examinee's creative personality. Details are given as follows:

\subsection{Questionnaire Investigation}

Two different teaching methods were employed to the same content, followed by questionnaire survey. The questionnaire mainly includes the following information:

(1) Basic Material: students' age, gender, former residence, school, parents' cultural background and occupation

(2) Attitudes toward teaching methods

a. How has your interest in this course been changed?

b. How well do you grasp relevant knowledge in this course?

c. How are you interested in this course? 


\subsection{Williams' Creativity Scale}

Including 50 optional questions, this scale inquires about the examinee's opinions, coving 4 sub-dimensions of adventure, curiosity, imagination and challenge. For each question, there are three scores: 3 refers to "quite suitable", 2 refers to "partly suitable" and 1 refers to "quite unsuitable". Among these questions, 40 ones are scored forwardly and 10 ones inversely. 12 questions are related to adventure and challenge respectively while 13 ones to curiosity and imagination respectively. An examinee may get a score as high as 150 or as low as 50 . A higher score indicates higher creativity.

\subsection{Implementation of Test}

A whole class of about 30 students took the test together within 20 to 25 minutes. Before the test, the examiner explained instructions until the examinees understood them.

\section{Result and Analysis}

Based on the questions preset to be answered as well as assumptions, we analyzed the result of the questionnaire investigation and drew conclusions as well.

\subsection{Students' Attitudes to Two Teaching Methods}

\section{Insert Table 2 Here}

As is revealed from the above data, when given the same content, students practice after learning in the class with the traditional teaching method while the task-based method enables students to learn during the process of solving problems and therefore appeals more to students. In addition, it is also obvious that teachers' teaching methods influence the improvement of students' learning interest, which, as a non-intelligent factor, has a direct effect on students' learning quality and creativity.

\subsection{Students' Creativity Tendency}

(1) Overall comparison between two groups in creativity tendency

\section{Insert Table 3 Here}

There is a great disparity in creativity tendency of the two groups $(\mathrm{F}=4.2, \mathrm{P}<0.05)$. As to the average, the experiment group has shown obviously higher creativity tendency than the control group. In the aspect of mean square deviation, the experiment group is also superior to the control one.

(2) Analysis on the development tendency of sub-dimensions of creativity tendency

Imagination: in this dimension, there is an overall disparity between two classes.

\section{Insert Table 4 Here}

There is a great disparity in imagination of the two groups $(\mathrm{F}=4.2, \mathrm{P}<0.05)$. It is revealed in variance that there is no obvious difference between the two groups. In the tendency of the average, that related to imagination of the experiment group is obviously higher than that of the control one.

Adventure: the average of adventure is higher in the experiment group than in the control group. But there is no obvious difference in the two classes in mean square deviation.

\section{Insert Table 5 Here}

Curiosity: There is an obvious disparity in curiosity displayed in the two classes ( $\mathrm{F}=8.8668)$, so is in the average. But there is no obvious difference in mean square deviation.

\section{Insert Table 6 Here}

Challenge: No obvious difference is shown in the two groups $(\mathrm{F}=0.319)$.

\section{Insert Table 7 Here}

\section{Conclusion}

After a term's teaching research on the task-based teaching method as well as relevant questionnaire investigation and measurement based on Williams' Creativity Scale, we have come to the following conclusions:

1) The task-based teaching method has an obvious positive influence on cultivating students' creativity tendency in vocational teaching.

As is shown in the above analysis, there are great differences between the two groups in creativity tendency as well as three sub-dimensions including curiosity, adventure and imagination. Only in challenge is there no obvious difference, which may result from the fact that most students are the only child in their families and have 
superior living conditions, hence not good at facing challenges and having no experience in it.

Creative tendency falls into the category of creative personality. Whether creative personality is characterized by consistence regardless of time determines whether it can serve as a standard to distinguish individual creativity. After his series of researches, Foryst (Zhang, Sternber, 2002) claims that creative personality is consistent. The result of our analysis, different from that of Foryst's study, reveals that students' creativity tendency may display differences in some special situations (e.g. with different teaching methods). However, in order to gain greater support for this result, more samples and a longitudinal study method should be employed in further studies.

2) This teaching method helps to enhance students' learning interest and further influence their creativity tendency.

We find from the analysis on these questionnaires that the task-based teaching method has obviously improved students' interest in study, enhanced their understanding capacity and therefore directly improved their curiosity. In the measurement of students' curiosity tendency with William's method, obvious differences are shown between the experiment group and the control one, which proves that the task-based teaching method has an obvious positive influence on students' creativity tendency. It is just like this:

The task-based method $\Longrightarrow$ enhancing learning interest $\Longrightarrow$ improving students' curiosity $\quad \Longrightarrow$ improving their creativity

3) Assumptions for further research

When employing the task-based method, samples should be increased or the experiment period should be prolonged to one semester so that more valid conclusions and better experiment effect can be achieved if time and man power permit. The measurement tools employed in this research is to be amended and tested in validity and reliability to meet the demand of diversified measurement. In such a study, some variables should be controlled such as students' personality, learning motivation and their motivation for offering answers. Although the task-based method is an effective one, due to the short time students have been in touch with it as well as students' high independence, it is difficult sometimes to reach an agreement during the course of cooperative learning. Accordingly, greater efforts should be made at different educational stages to enhance cooperation and communication skills.

\section{References}

Dai, Zhongheng. (1986). Measurement of Psychology and Education. Shanghai: East China Normal University Press.

Li, Jiazeng. (2007). Exploration and Experience in Curriculum Pattern on Developing Students' Creativity. Journal of Macao University of Science and Technology. (1).

P. TORRANCE E, A. SISK D. (1997). Teaching Gifted and Talented Children in the Regular Classroom. USA: Creative Education Foundation Press.

Tang, Zhilong. Research on Creativity of Students Specialized in Mechanical Engineering and Relevant Factors. Thesis for Doctoral Degree of Industrial Education Research Institute of National Taiwan Normal University. p87.

Zhang, Qinglin \& Sternberg, Robert J. (2002). Manual of Creativity Research. Sichuan: Sichuan Education Press, pp76-78, pp320-321. 
Table 1. Distribution of Samples

\begin{tabular}{|c|c|c|c|}
\hline Class & Male & Female & Total \\
\hline Class One (experiment) & 30 & 1 & 31 \\
\hline Class Two (control) & 30 & 0 & 30 \\
\hline Total & 60 & 1 & 61 \\
\hline
\end{tabular}

Table 2.1. How has your interest in this course been changed?

\begin{tabular}{|c|c|c|}
\hline Item & $\begin{array}{l}\text { The control } \\
\text { class }(\%)\end{array}$ & $\begin{array}{l}\text { The experiment } \\
\text { class }(\%)\end{array}$ \\
\hline Always interested & 40.9 & 80.3 \\
\hline $\begin{aligned} \text { interested } & \longrightarrow \text { less interested } \longrightarrow \\
& \text { interested }\end{aligned}$ & 8.2 & 6.5 \\
\hline Increasingly interested & 30.6 & 7.8 \\
\hline Less interested & 6.1 & 0 \\
\hline Not quite interested or uninterested & 12.2 & 4.4 \\
\hline Always not interested & 2 & 1 \\
\hline
\end{tabular}

Table 2.2. How well do you grasp relevant knowledge in this course?

\begin{tabular}{|c|c|c|}
\hline Item & $\begin{array}{c}\text { The control } \\
\text { class }(\%)\end{array}$ & $\begin{array}{c}\text { The experiment } \\
\text { class }(\%)\end{array}$ \\
\hline Very clear & 54.8 & 75.6 \\
\hline Understanding but not clear & 41.6 & 22.4 \\
\hline Entirely blank & 3.6 & 2 \\
\hline
\end{tabular}

Table 2.3. How are you interested in this course?

\begin{tabular}{|l|c|c|}
\hline \multicolumn{1}{|c|}{ Item } & $\begin{array}{c}\text { The control } \\
\text { class }(\%)\end{array}$ & $\begin{array}{c}\text { The experiment } \\
\text { class( } \%)\end{array}$ \\
\hline Rich, interesting and practical content & 49.6 & 65.8 \\
\hline Rich content except for some dull things & 49.2 & 33.2 \\
\hline Boring and dull content & 1.2 & 1 \\
\hline
\end{tabular}


Table 3. The average scores of the experiment group and the control group in creativity tendency

$\mathrm{F}=5.1301$

\begin{tabular}{|l|l|l|}
\hline Grade & $\begin{array}{l}\text { The } \\
\text { experiment } \\
\text { class }\end{array}$ & $\begin{array}{l}\text { The control } \\
\text { class }\end{array}$ \\
\hline $\mathrm{X}$ & 113.6325 & 103.7462 \\
\hline $\mathrm{S}$ & 7.8599 & 8.3228 \\
\hline
\end{tabular}

Table 4. The average scores of the experiment group and the control group in imagination

$\mathrm{F}=7.1394$

\begin{tabular}{|l|l|l|}
\hline Grade & $\begin{array}{l}\text { The } \\
\text { experiment } \\
\text { class }\end{array}$ & $\begin{array}{l}\text { The control } \\
\text { class }\end{array}$ \\
\hline X & 29.8375 & 26.2911 \\
\hline S & 4.8426 & 4.4850 \\
\hline
\end{tabular}

Table 5. The average scores of the experiment group and the control group in adventure

$\mathrm{F}=6.0070$

\begin{tabular}{|l|l|l|}
\hline Grade & $\begin{array}{l}\text { The } \\
\text { experiment } \\
\text { class }\end{array}$ & $\begin{array}{l}\text { The control } \\
\text { class }\end{array}$ \\
\hline $\mathrm{X}$ & 24.6702 & 22.8236 \\
\hline $\mathrm{S}$ & 3.0896 & 2.9911 \\
\hline
\end{tabular}

Table 6. The average scores of the experiment group and the control group in Curiosity

$\mathrm{F}=8.8668$

\begin{tabular}{|l|l|l|}
\hline Grade & $\begin{array}{l}\text { The } \\
\text { experiment } \\
\text { class }\end{array}$ & $\begin{array}{l}\text { The control } \\
\text { class }\end{array}$ \\
\hline $\mathrm{X}$ & 34.2559 & 31.1021 \\
\hline $\mathrm{S}$ & 4.1087 & 3.9335 \\
\hline
\end{tabular}

Table 7. The average scores of the experiment group and the control group in Challenge

\begin{tabular}{|l|l|l|}
\hline Grade & $\begin{array}{l}\text { The } \\
\text { experiment } \\
\text { class }\end{array}$ & $\begin{array}{l}\text { The control } \\
\text { class }\end{array}$ \\
\hline $\mathrm{X}$ & 27.8732 & 25.9487 \\
\hline $\mathrm{S}$ & 2.8658 & 3.0664 \\
\hline
\end{tabular}

$\mathrm{F}=6.8565$ 